\title{
Experimental study on effect by cementation on self-sealing capability of bentonite buffer material
}

\author{
Daichi Ito $^{1 *}$, Hideo Komine ${ }^{1}$, and Hailong Wang ${ }^{1}$ \\ ${ }^{1}$ Waseda University, Department of Civil and Environmental Engineering, 3-4-1 Okubo Shinjuku Tokyo, Japan
}

\begin{abstract}
In Japanese project for disposal of high-level radioactive waste, the self-sealing capability of bentonite buffer material, which results from the swelling deformation to fill the gaps between waste container and wall of disposal pit, must be retained thousands of years. However, because of the effect of high pressures, occurrence of cementation and property changes of the buffer material are a concern. Few studies had examined cementation effects because of the difficulties for simulating long-term alteration process experimentally. In this paper, swelling properties of consolidated buffer are regarded as similar as those of naturally consolidated bentonite ore. Therefore, three kinds of bentonite ores were used for experiments to elucidate influences of cementation on self-sealing capabilities. Undisturbed and reconstituted specimens were prepared to assess their swelling pressures after filling a preset gap in a swelling pressure apparatus. Results show that for Japanese ores, the swelling pressure of undisturbed specimens is about half that of reconstituted specimens. For American and Chinese ores, the difference of swelling pressure is greater when the preset gap is smaller. Results imply that effects of cementation on self-sealing capability are smaller when swelling deformation is allowed.
\end{abstract}

\section{Background}

For geological disposal of high-level radioactive waste (HLW), compacted bentonite is slated for using as buffer and back-filling materials [1-3]. Fig. 1 presents a Japanese conceptual example of deposition facilities constructed to depth of several hundred meters [4]. The function of buffer material is to separate HLW from the surrounding environment and to delay the leakage of radionuclide into groundwater. Therefore, buffer material should have low permeability and self-sealing capability, which means buffer material absorbs ground water [5] and seal the surrounding gaps by swelling deformation. In the initial state of HLW deposition facility, unavoidable gaps are expected to exist between canister and buffer materials, and between the buffer and the host rock. Some studies have specifically examined the effects of gaps on the swelling and hydro-mechanical properties of bentonite materials [6-9]. In addition to these gaps in initial states, buffer material is necessary to seal gaps occurring after a long period of time because of host rock deformation [10].

Meanwhile, because thousands of years are needed during the decay of the HLW radioactivity, long-term changes of buffer material properties must be considered when designing underground facilities. Considering conditions such as temperature, ground-water salinity and high compressive pressure because of earth pressure and corroded expansion of canister, there is highly possibility that cementation would occur in the bentonite buffer material. Here in this paper, cementation is referred as a part of diagenesis and a kind of bond among soil particles by precipitation of minerals such as amorphous silica, carbonates, aluminum hydroxide because of increase of temperature and pressure during the burial process of sediments [11,12]. Furthermore, cementation changes the swelling and self-sealing properties of bentonite. However, because of difficulties for simulating long-term alteration processes experimentally, few studies have accurately evaluated cementation effects. One study targeted natural bentonite beds placed deep underground to evaluate smectite longterm stability and changes [13], and another study assessed engineering properties such as consolidation and strength characteristics [14]. Based on the explanation presented above, the authors hypothesized that consolidated buffer material will have similar physical properties to those of bentonite ore formed by sequential consolidation in natural ground.

In this paper, we quantitatively investigated the influence of cementation on the self-sealing capability of bentonite to verify its long-term retention capabilities. Bentonite raw ores of three kinds were selected. Pressure after gap filling by swelling of undisturbed and reconstituted specimens was measured onedimensionally.

\section{Material and methods}

Bentonite ores of three types were used. They were mined respectively in Japan, China and the United States of America. Japanese ores were from Tsukinuno Clay

\footnotetext{
* Corresponding author: daichi_ito@akane.waseda.jp
} 


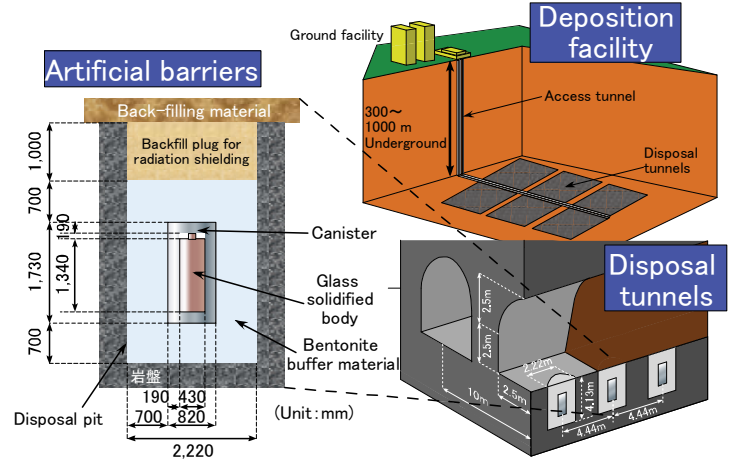

Fig. 1. Japanese conceptual example of deposition facility of HLW.

Mine (Kunimine Inds. Co. Ltd.), which is the origin of Kunigel V1 (KV1). Chinese ores were from Liufangzi Clay Mine (Jilin province). American ores were from Ten Sleep Clay Mine (Wyoming). Fig. 2 presents the appearances of each ore sample. Some geological reports have described that these ores were formed by diagenesis [15-17]. Table 1 presents fundamental properties of ores. Measuring methods of soil particle density, liquid limit, and plastic limit were referred Komine \& Ogata [18]. Montmorillonite contents were based on the Methylene Blue adsorption test [19]. Swelling power was measured by detecting the volume when $2 \mathrm{~g}$ of dried bentonite sample was dissolved in $100 \mathrm{ml}$ of dissolved water [20]. Cation exchange capacity (CEC) and exchange capacity of $\mathrm{Na}^{+}, \mathrm{Ca}^{2+}, \mathrm{Mg}^{2+}, \mathrm{K}^{+}$were measured according to JGS0261-2009 [21].

In this study, undisturbed specimens are regarded to be affected by cementation. On the other hand, for reconstituted specimens, the effect of cementation is thought to be partially removed. These specimens were prepared by the following method. Undisturbed specimens were prepared using trimming tools such as cutter rings, knives and trimmers to produce a cylindrical shape without fragments and cracks. However, when making the reconstituted specimens, a powdered sample obtained by grinding the ore was sieved through 0.425 $\mathrm{mm}$ sieve. Then a static load was applied to the sample until the dry density reached the same degree as that of
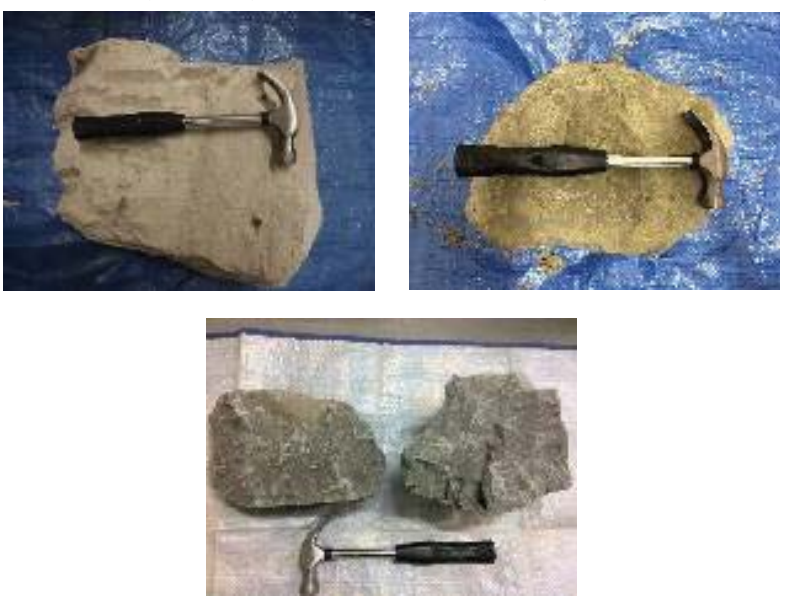

Fig. 2. Japanese (top left), American (top right) and Chinese ores (bottom).
Table 1. Fundamental properties of Japanese, American and Chinese ore

\begin{tabular}{|c|c|c|c|}
\hline & $\begin{array}{c}\text { Japanese } \\
\text { ore }\end{array}$ & $\begin{array}{c}\text { American } \\
\text { ore }\end{array}$ & $\begin{array}{c}\text { Chinese } \\
\text { ore }\end{array}$ \\
\hline $\begin{array}{l}\text { Soil particle density } \\
\left(\mathrm{g} / \mathrm{cm}^{3}\right)\end{array}$ & 2.77 & 2.67 & 2.73 \\
\hline Liquid limit (\%) & 419.1 & 588.2 & 541.6 \\
\hline Plastic limit (\%) & 29.2 & 57.2 & 35.6 \\
\hline Plasticity index & 389.9 & 531.0 & 506.0 \\
\hline $\begin{array}{l}\text { Content of } \\
\text { montmorillonite (\%) }\end{array}$ & 44.7 & 50.4 & 51.1 \\
\hline $\begin{array}{l}\text { Swelling power } \\
(\mathrm{ml} / 2 \mathrm{~g})\end{array}$ & 12 & 16 & 13 \\
\hline $\mathrm{CEC}(\mathrm{cmol}(+) / \mathrm{kg})$ & 39.3 & 38.8 & 39.4 \\
\hline $\begin{array}{l}\text { Exchange capacity } \\
\mathrm{Na}^{+}(\operatorname{cmol}(+) / \mathrm{kg})\end{array}$ & 42.5 & 53.8 & 42.3 \\
\hline $\begin{array}{l}\text { Exchange capacity } \\
\mathrm{Ca}^{2+}(\mathrm{cmol}(+) / \mathrm{kg})\end{array}$ & 10.2 & 17.8 & 20.1 \\
\hline $\begin{array}{l}\text { Exchange capacity } \\
\mathrm{Mg}^{2+}(\mathrm{cmol}(+) / \mathrm{kg})\end{array}$ & 0.8 & 0.4 & 3.7 \\
\hline $\begin{array}{l}\text { Exchange capacity } \\
\mathrm{K}^{+}(\operatorname{cmol}(+) / \mathrm{kg})\end{array}$ & \multicolumn{3}{|c|}{$\begin{array}{l}\text { Lower than the minimum } \\
\text { determination limit }(0.8)\end{array}$} \\
\hline $\begin{array}{l}\text { Initial dry density of } \\
\text { undisturbed } \\
\text { specimens }\left(\mathrm{Mg} / \mathrm{m}^{3}\right)\end{array}$ & $1.55-1.79$ & $1.48-1.60$ & $\begin{array}{c}1.84- \\
1.93\end{array}$ \\
\hline $\begin{array}{l}\text { Mineral composition } \\
\text { except for } \\
\text { montmorillonite }\end{array}$ & $\begin{array}{l}\text { Quartz, } \\
\text { Plagioclase, } \\
\text { Calcite }\end{array}$ & $\begin{array}{c}\text { Plagioclase, } \\
\text { Cristobalite, } \\
\text { Dolomite }\end{array}$ & $\begin{array}{l}\text { Plagio- } \\
\text { clase, } \\
\text { Quartz }\end{array}$ \\
\hline $\begin{array}{l}\text { Approximate } \\
\text { geological age } \\
\text { (million years) }\end{array}$ & 10 & 100 & 150 \\
\hline
\end{tabular}

undisturbed specimen. All specimens were cylindrical shaped with $28 \mathrm{~mm}$ diameter and $10 \mathrm{~mm}$ height. Additionally, no water was added while preparing specimens.

\section{Overview of the one-dimensional self- sealing test}

Fig. 3 presents the overview of the test device [8]. The test device consists of a frame, a bellofram cylindar, a clampknob for suppressing deformation, a load cell with $50 \mathrm{kN}$ maximum capacity, and a minimum scale of 0.012 $\mathrm{kN}$, a displacement gauge with maximum capacity of 25 $\mathrm{mm}$ and a minimum scale of $0.002 \mathrm{~mm}$, and an SUS316L container. The test container includes a pedestal, piston, bottom plate, and porous metal. Deformation toward the horizontal direction is constrained by ring.

The one-dimensional self-sealing test procedure is described as below as also illustrated in Fig. 4. First, specimens were moved into the stainless steel ring. Second, the test container was assembled and moved 


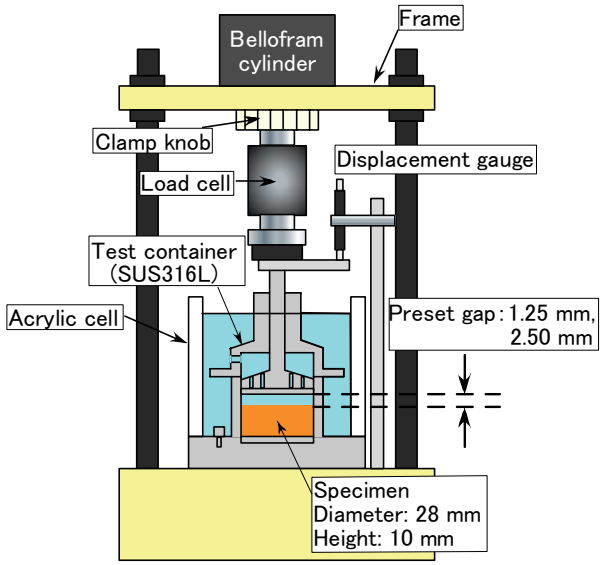

Fig. 3. One-dimensional self-sealing test device.

into the frame. The piston was entirely contacted to the specimen top surface with a $20-30 \mathrm{kPa}$ load. At this moment, the displacement gauge value was initialized. Then, the piston was fixed to a load cell and elevated until the predetermined gap with lowering of the air pressure. After gap width confirmination, the piston displacement was fixed by tightening the clamp knob. Finally, distilled water was filled into the acrylic cell. Measurement of the load cell and displacement gauge was started. The test was continued until the pressure settled to a constant value. After the test, the specimen dry density was recalculated considering the gap.

For this test, gaps of two types $(1.25 \mathrm{~mm}$ and 2.50 $\mathrm{mm}$ ) were set up for the specimens. The gap width was determined by referring the Japanese designing plan [3]. In this plan, the gap separating the buffer and host rock would be required $40 \mathrm{~mm}$. The gap separating the canister and buffer would be $10 \mathrm{~mm}$ to provide workability. The total gap width would be $50 \mathrm{~mm}$ in total. This value is one-eighth of the thickness of bufer material $(400 \mathrm{~mm})$. Therefore, for this test, the gap for specimens was set analogously in one-dimension for one-eighth and the twice one-fourth of the specimens' height of $10 \mathrm{~mm}$. And, distilled water was supplied from the gap side above the specimens, simulating the direction of groundwater permeation in an actual disposal pit.
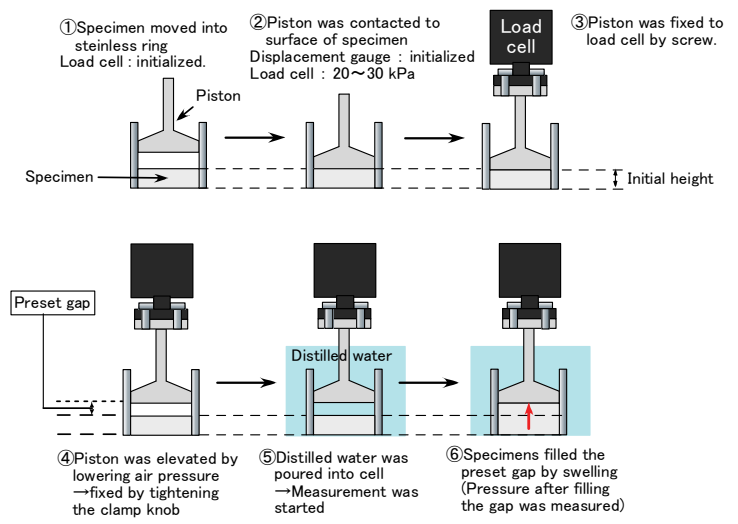

Fig. 4. The conceptual figure of procedure of the onedimensional self-sealing test.

\section{One-dimensional self-sealing test results}

Table 2 shows the test conditions and results. Fig. 5-7 portray time-pressure relation after filling the $1.25 \mathrm{~mm}$ gap. As shown in these figures, the pressure of both reconstituted specimens and undisturbed specimens was measured immediately after the start of testing in each ore. In these cases, it may be said that the cementation has little effect on the necessary time for gap filling by swelling deformation. From the perspective of the pressure after gap filling, a tendency is apparent by which measured pressure for undisturbed specimens were significantly lower than those of reconstituted specimens in each ore. In Japanese ores, the values of undisturbed specimens $(520 \mathrm{kPa}, 580 \mathrm{kPa})$ were about half of those obtained from the reconstituted specimens $(280,360 \mathrm{kPa})$. Furthermore, the values of undisturbed specimens in American and Chinese ores were less than one-fourth of those of the reconstituted specimens.

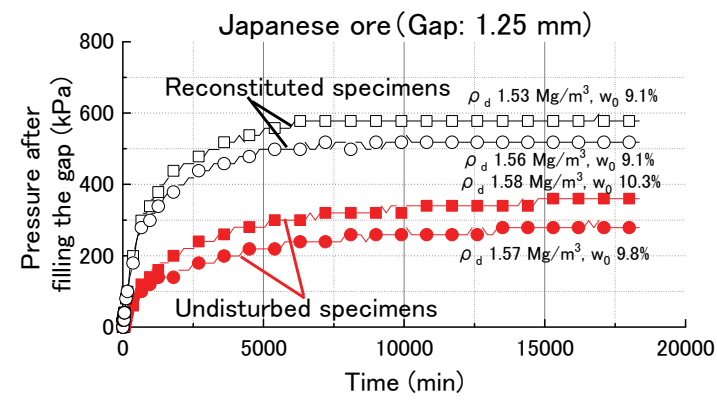

Fig. 5. Time-pressure relation after gap filling (Japanese ore, gap: $1.25 \mathrm{~mm})$.

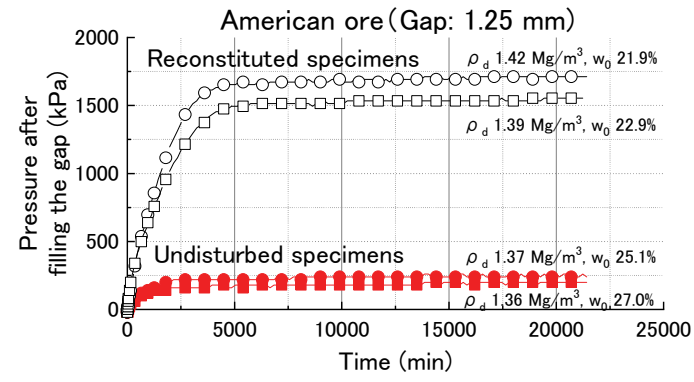

Fig. 6. Time-pressure relation after gap filling (American ore, gap: $1.25 \mathrm{~mm}$ ).

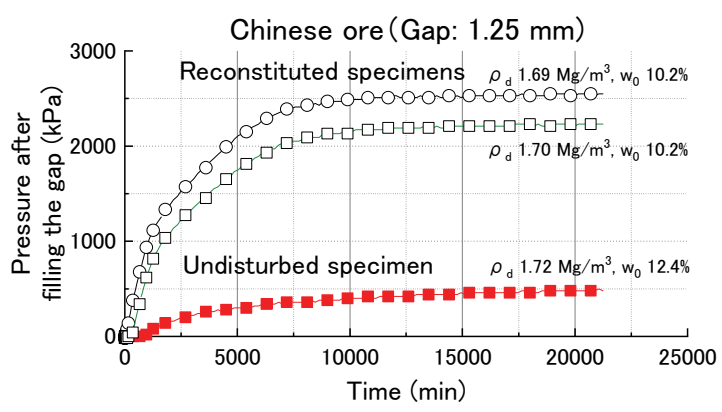

Fig. 7. Time-pressure relation after gap filling (Chinese ore, gap: $1.25 \mathrm{~mm}$ ). 
Fig. 8-10 show the time-pressure relation after filling the $2.50 \mathrm{~mm}$ gap. For Japanese ores, one of the undisturbed specimens took more than 5000 minutes to generate pressure after filling the gap. For undisturbed specimens of the American ore, it took about 30000 minutes to observe the pressure in one case, and there was no observation of pressure in another case. These results suggest that gap filling by swelling deformation can be reduced considerably because of the increase of gap resulting from cementation. Furthermore, the pressure of undisturbed specimens was about half of those from reconstituted specimens in Japanese and Chinese ores, and about one-third of that assessed from American ore, as in the case of $1.25 \mathrm{~mm}$ gap.

Also, focusing on the initial water content of the specimens in Table 2, the initial water content of reconstituted specimens was about $5 \%$ lower than that of the undisturbed specimens in $2.5 \mathrm{~mm}$ gap case of Japanese, American and Chinese ores. The reason is that water contained in the ores was evaporated during preparation of the reconstituted specimens such as crushing. Komine \& Ogata (1994) showed experimental results that initial water content has little impact on swe-

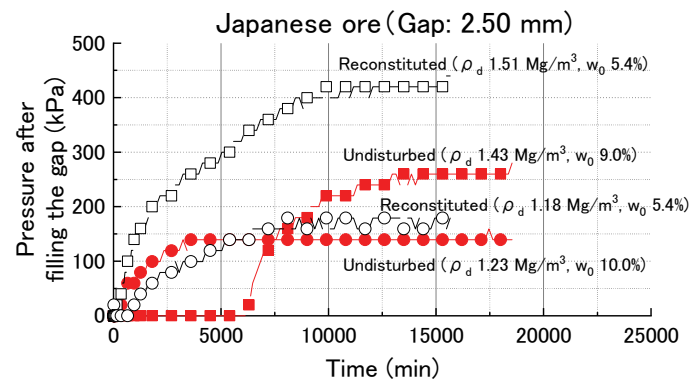

Fig. 8. Time-pressure relation after gap filling (Japanese ore, gap: $2.50 \mathrm{~mm}$ ).

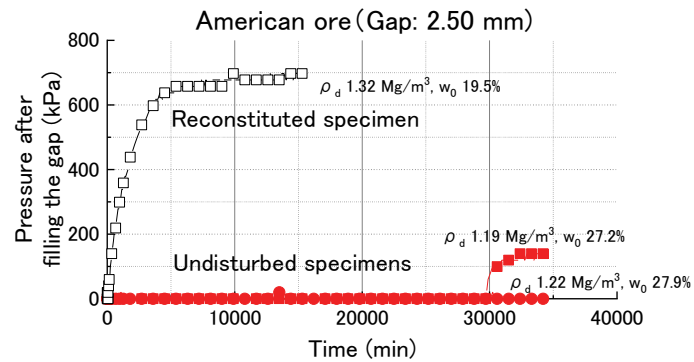

Fig. 9. Time-pressure relation after gap filling (American ore, gap: $2.50 \mathrm{~mm}$ ).

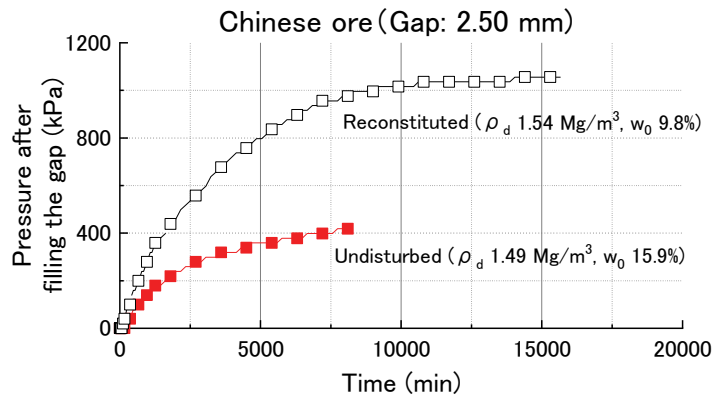

Fig. 10. Time-pressure relation after gap filling (Chinese ore, gap: $2.50 \mathrm{~mm}$ ). lling pressure and swelling deformation in Japanese bentonite $\mathrm{KV} 1$ in the range of 6 to $20 \%$ [22]. In addition, Baille et.al (2010) reported that swelling pressure of German bentonite mined from Bavaria has almost no effect in the range of initial water content of $10-40 \%$ [23]. Considering the researches mentioned above, in this paper, the difference of the initial water content might have a minor effect on the swelling pressure.

\section{Discussion}

From Fig 5-10, it can be seen when the gap is $1.25 \mathrm{~mm}$, it is completed immediately after the start of testing even in undisturbed specimens, but when the gap is $2.50 \mathrm{~mm}$, the filling time increases considerably. From these experimentally obatained results, assuming an actual disposal hole, if a gap exists with width of $25 \%$ of the buffer material thickness, the gap might not be filled because of cementation effects. Therefore, when installing the canister and buffer material in the disposal hole, one must take efforts during construction, such as gap filling in advance by inputting soil materials to minimize the gaps, to compensate for buffer material self-sealing property deterioration over time.

Next, cementation effects on the pressure after gap filling are discussed based earlier results reported by the authors for one-dimensional self-sealing tests and swelling pressure tests [24]. In the swelling pressure test, the swelling pressure was measured using the same test equipment as that used for the one-dimensional selfsealing test, under the condition in which vertical displa-

Table 2. Test conditions and results

\begin{tabular}{|c|c|c|c|c|c|}
\hline & \multicolumn{2}{|c|}{$\begin{array}{c}\text { Dry density } \\
\left(\mathrm{Mg} / \mathrm{m}^{3}\right)\end{array}$} & \multicolumn{2}{c|}{$\begin{array}{c}\text { Water } \\
\text { content (\%) }\end{array}$} & $\begin{array}{c}\text { Maximum } \\
\text { Pressure } \\
\end{array}$ \\
\cline { 2 - 5 } Before & After & Before & After & (ka) \\
\hline Jpn., Un., 1.25 & 1.77 & 1.57 & 10.3 & 33.8 & 360 \\
\hline Jpn., Un., 1.25 & 1.76 & 1.57 & 9.8 & 34.4 & 279 \\
\hline Jpn., Re., 1.25 & 1.71 & 1.53 & 9.1 & 29.3 & 578 \\
\hline Jpn., Re., 1.25 & 1.75 & 1.55 & 9.1 & 30.2 & 518 \\
\hline Jpn., Un., 2.50 & 1.79 & 1.43 & 9.0 & 41.6 & 280 \\
\hline Jpn., Un., 2.50 & 1.55 & 1.23 & 10.0 & 54.1 & 159 \\
\hline Jpn., Re., 2.50 & 1.87 & 1.51 & 5.4 & 43.7 & 440 \\
\hline Jpn., Re., 2.50 & 1.45 & 1.18 & 5.4 & 52.6 & 179 \\
\hline Ame., Un., 1.25 & 1.54 & 1.37 & 25.1 & - & 199 \\
\hline Ame., Un., 1.25 & 1.60 & 1.36 & 27.0 & - & 240 \\
\hline Ame., Re., 1.25 & 1.60 & 1.42 & 21.9 & - & 1713 \\
\hline Ame., Re., 1.25 & 1.58 & 1.39 & 21.9 & 50.7 & 1554 \\
\hline Ame., Un., 2.50 & 1.48 & 1.18 & 27.2 & 62.6 & 139 \\
\hline Ame., Un., 2.50 & 1.53 & 1.22 & 27.9 & 48.9 & - \\
\hline Ame., Re., 2.50 & 1.66 & 1.32 & 19.5 & 55.2 & 697 \\
\hline Chn., Un., 1.25 & 1.93 & 1.72 & 12.4 & 33.3 & 480 \\
\hline Chn., Re., 1.25 & 1.91 & 1.69 & 10.2 & - & 2549 \\
\hline Chn., Re., 1.25 & 1.92 & 1.70 & 10.2 & 35.4 & 2231 \\
\hline Chn., Un., 2.50 & 1.84 & 1.49 & 15.9 & 37.7 & 498 \\
\hline Chn., Re., 2.50 & 1.93 & 1.54 & 9.8 & 39.8 & 1056 \\
\hline & & & & & \\
\hline
\end{tabular}




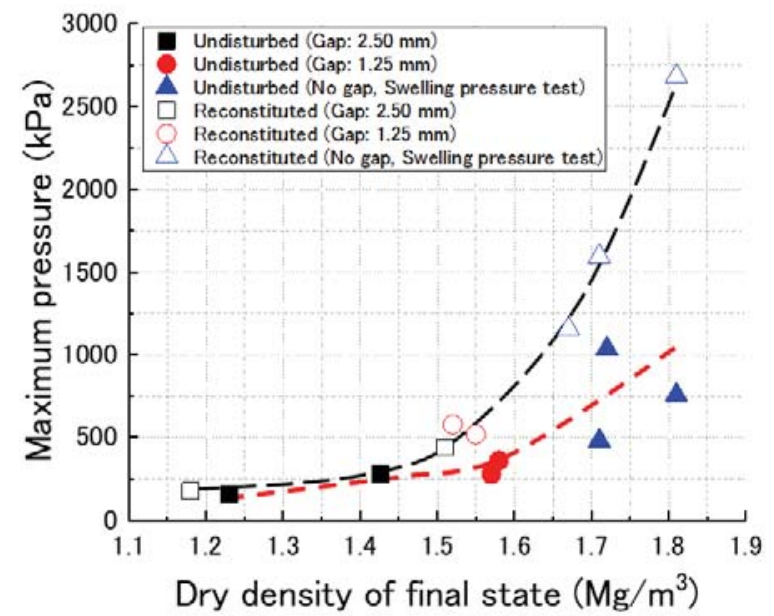

Fig. 11. Relation between dry density of the final state and pressure in one-dimensional self-sealing test and swelling pressure test (Japanese ore).

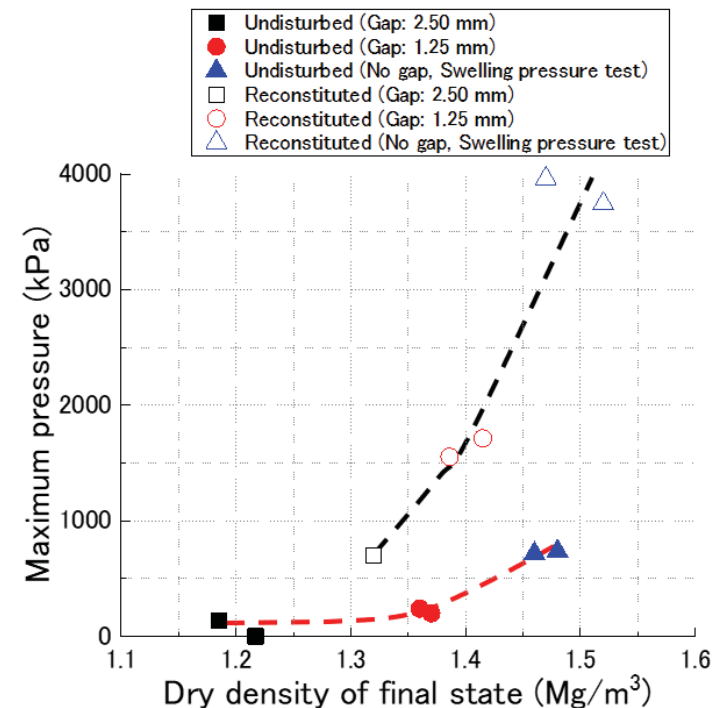

Fig. 12. Relation between dry density of the final state and pressure in one-dimensional self-sealing test and swelling pressure test (American ore).

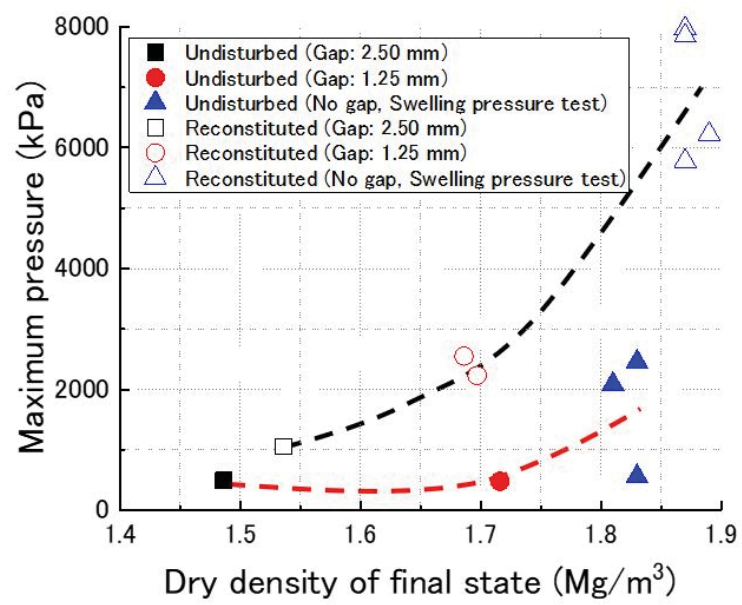

Fig. 13. Relation between dry density of the final state and pressure in one-dimensional self-sealing test and swelling pressure test (Chinese ore). cement was suppressed with no gap.

Fig. 11-13 show relations for Japanese, American and Chinese ores between the dry density at the end of test and the maximum pressure of both the onedimensional self-sealing tests and the swelling pressure tests. These results for undisturbed specimens and reconstituted specimens show that the pressure tended to increase along with the dry density. The values and increasing tendency of reconstituted Japanese ore specimens were similar to those obtained from KV1 in earlier studies $[8,25]$. In Japanese ore, when the dry density is around $1.6 \mathrm{Mg} / \mathrm{m}^{3}$, the pressure of the undisturbed specimens is about two-thirds that of the reconstituted specimens, and about one-third at 1.8 $\mathrm{Mg} / \mathrm{m}^{3}$. In other words, the difference in pressure increases as the dry density increases. A similar tendency is observed for American and Chinese ores, but the differences between undisturbed and reconstituted specimens of pressure values is greater than that for Japanese ore. Presumably, swelling pressure properties and self-sealing capabilities declined because of the stronger influence of cementation, because American and Chinese ores are older than Japanese ores in terms of geological age. The tendency shown by these results indicates that, under conditions where volume change of the specimen is suppressed strongly, such as the swelling pressure test, the cementation effect becomes stronger than in the self-sealing test, in which swelling deformation is allowed. Fig. 14 presents the conceptual mechanism of the cementation effect on swelling properties of undisturbed specimens. With swelling deformation without volume suppression, as the swelling deformation caused by water absorption of montmorillonite progresses, the adhesion among particles attributable to the cementation substance gradually degrades. On the other hand, under conditions such as the swelling pressure test with a volume constraint, it is considered that the water absorption of montmorillonite is inhibited by adhesion effects among particles, therefore, swelling pressure development keep suppressed.

Based on the discussion above, if the gap is less than $12.5 \%$ of the buffer material thickness, then the gap can be filled; moreover, the self-sealing property is sufficiently satisfied, even if the buffer material becomes altered by cementation. However, if the gap becomes larger than $12.5 \%$ because of the preset gap or fault displacement of the host rock, then the gap cannot be filled. Instead, it remains as the water path. Therefore, it is necessary to take measures during construction such as filling the gaps to the greatest extent possible.

\section{Conclusion}

One dimensional self-sealing property of three kinds of bentonite ores were evaluated experimentally in the range of initial dry density of $1.45-1.93 \mathrm{Mg} / \mathrm{m}^{3}$ and initial water content of $5-28 \%$. For a $1.25 \mathrm{~mm}$ gap, both the undisturbed specimens and the reconstituted specimens immediately filled the gap through swelling deformation, although it took a long time to fill the gap 


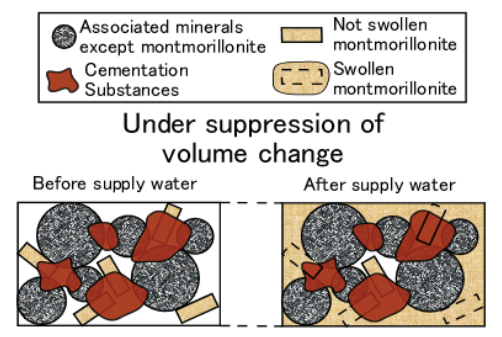

- Water absorption of montmorillonite is restricted by the effect of the adhesion between particles by cementation. Development of pressure is suppressed throughout.

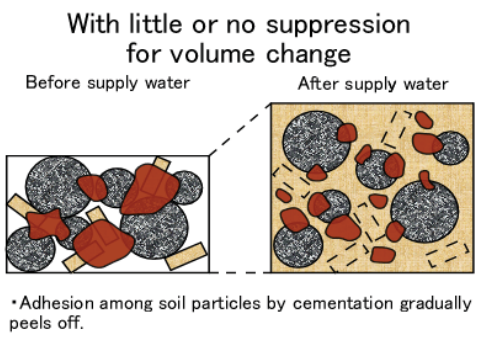

Fig. 14. Conceptual mechanism of cementation effect on swelling properties of undisturbed specimens.

in undisturbed specimens in the case of a $2.50 \mathrm{~mm}$ gap. These results suggest that when a gap of $25 \%$ of the buffer material thickness is formed, cementation will cause significant delay in filling. It might even make filling impossible. Under conditions in which the volume constraint of the specimen is weak, the influence of cementation on pressure after gap filling tends to be weaker. These facts indicate that if the gap is $12.5 \%$ or less of the buffer mterial thickness, then the gap can be filled even if cementation occurs.

This work was supported by the Ministry of Economy, Trade and Industry (METI) of Japan, JSPS KAKENHI Grant Number JP18H01534 and the Research Institute of Sustainable Future Society, Waseda Research Institute for Science and Engineering, Waseda University. The authors also thank Dr. M. Ito (Kunimine Ind. Co. Ltd.) for providing bentonite ore samples.

\section{References}

1. R. Pusch, Use of bentonite for isolation of radioactive waste products, Clay Minerals, 27, 353361 (1992)

2. Japan Nuclear Cycle Development Institute, H12: project to establish the scientific and technical basis for HLW disposal in Japan -project overview report, JNC TN1400 99-022 (1999)

3. N. Ogata, A. Kosaki, H. Ueda, H. Asano, H. Takao, Execution techniques for high level radioactive waste disposal: IV design and manufacturing procedure of engineered barriers, J. Nucl. Fuel Cycle Environ., 5(2), 103-121 (1999)

4. Japan Atomic Energy Agency, Current research and development on geological disposal technology at the Japan Atomic Energy Agency (JAEA), Geological Disposal Research and Development
Coordination $1^{\text {st }}$ Meeting (May 31 $1^{\text {st }}, 2017$ ), https://www.meti.go.jp/committee/kenkyukai/energ y environment/chisou shobun chousei/pdf/001 02 02.pdf, p.29 (2017)

5. H. Wang, T. Shirakawabe, H. Komine, D. Ito, T. Gotoh, Y. Ichikawa, Q. Chen, Movement of water in compacted bentonite and its relation with swelling pressure, Canadian Geotechnical Journal, doi:10.1139/cgj-2019-0219 (2019)

6. Q. Wang, A.M. Tang, Y.J. Cui, P. Delage, J.D. Barnichon, W.M. Ye, The effect of technological voids on the hydro-mechanical behaviour of compacted bentonite-sand mixture, Soils and Foundations, 53(2), 232-245 (2013)

7. L.Y. Jia, Y.G. Chen, W.M. Ye, Y.J. Cui, Effects of a simulated gap on anisotropic swelling pressure of compacted GMZ bentonite, Engineering Geology, 248, 155-163 (2019)

8. H. Komine, N. Ogata, A. Nakashima, H. Takao, H. Ueda, T. Kimoto, Evaluation of self-sealing property of bentonite-based buffer by onedimensional model test, Journal of JSCE, III-66, 101-112, (2004)

9. X. Bian, Y.J. Cui, X.Z. Li, Voids effect on the swelling behaviour of compacted bentonite, Geotechnique, 69-7, 593-605 (2019)

10. Nuclear Waste Management Organization of Japan, Safety features and technical requirements of disposal facility, p.24, NUMO-TR-10-11 (2011)

11. J. K. Mitchell, Kenichi Soga, Fundamentals of soil behavior (Third edition), John Wiley \& Sons, Inc., 437 (2005)

12. Japanese Geotechnical Society, Technical terms for soil engineering, pp. 70 (1996)

13. R. Pusch, Stability of deep-sited smectite minerals in crystalline rock -chemical aspects-, $S K B F-K B S$, TR83-16, 1-68 (1983)

14. I. Towhata, P. Kuntiwattanakul, K. Ohishi, N. Takeuchi, Effect of Temperature on mechanical behavior of clay, Soil Mechanics and foundation engineering, 46-10, 27-30 (1998)

15. M. Ito, T. Ishii, H. Nakashima, Y. Hirata, The study of genesis and formation condition of bentonite, Journal of the Clay Science Society of Japan, 38(3), 181-187 (1999)

16. J. M. Bremer, Stratigraphy and sedimentlogy of the cretaceous mowry shale in the northern bighorn basin of Wyoming: Implications for unconventional resource exploration and development, Digital Commons@University of Nebraska, 1-55 (2016)

17. K. Tomita, N. Zhang, Some natural Na-bentonites in China, Report of the Faculty of Science, Kagoshima University -Earth sciences and biology-, 23, 1-8 (1990)

18. H. Komine, N. Ogata, Evaluation of clay compaction characteristics by means of the plastic limit, Journal of JSCE, 436, III-16, 103-110 (1991) 
19. Japanese Industrial Standards, Test method for methylene blue adsorption on bentonite and acid clay, JIS Z 2451 (2019)

20. Japanese Bentonite Association, Japan Bentonite Association Standards, JBAS-104-77 (1977)

21. Japanese Geotechnical Society, Determination of cation exchange capacity, JGS0261-2009 (2009)

22. H. Komine, N. Ogata, Experimental study on swelling characteristics of compacted bentonite, Canadian Geotechnical Journal, 31(4), 478-490 (1994)

23. W. Baille, S. Tripathy, T. Schanz, Swelling pressures and one-dimensional compressibility behaviour of bentonite at large pressure, Applied Clay Science, 48, 324-333 (2010)

24. D. Ito, H. Komine, S. Morodome, T. Sekiguchi and G. Miura, Evaluating influence of cementation on bentonite buffer material based on the swelling properties of bentonite ore, Proceedings of the 8th International Congress on Environmental Geotechnics, 3, 97-104 (2018)

25. H. Komine, N. Ogata, Swelling characteristics of sand-bentonite mixture and various kinds of bentonite, Journal of JSCE, III-58, 373-385 (2002) 